\title{
PERFORMA AYAM RAS PETELUR COKLAT DENGAN FREKUENSI PEMBERIAN RANSUM YANG BERBEDA
}

\author{
Didik Margo Utomo \\ Jurusan Ilmu Ternak, Fakultas Peternakan, Universitas Islam Balitar \\ Jl. Majapahit No. 2-4 Kota Blitar, Jawa Timur 66131
}

Telp. 0342-4557025

\begin{abstract}
This aims of the study is to determine the effect of different feeding frequency on layer performance (feed intake, hen day production, egg weight, and feed conversion ration) Data experiment were held on $10^{\text {th }}$ April-10 $0^{\text {th }}$ July 2017 at Abas Farm, Ponggok subdistric, Blitar regency. Four hundred laying hens of ISA Brown strain age 30 weeks were used in this study and kept in individual cages. A randomized completely design was applied with 4 treatments and 5 replications. The treatment consists of P0: 2 times feeding, P1: 3 times feeding, P2: 4 times feeding, and P3: 4 times feeding. Data ware analyzed using analysis of variance at 5\% level and Duncan test at $5 \%$ level. The conclusion based on the result were: the treatments not significant $(P>0.05)$ on feed intake, egg weight, and feed conversion ration, but significant $(p<0.05)$ on hen day production. It's suggested to use 2 or 3 time feeding frequency.
\end{abstract}

Keyword: feeding frequency, performance, layer.

\section{PENDAHULUAN}

Peternakan ayam petelur coklat merupakan salah satu bidang usaha yang dapat dikembangkan untuk memenuhi kebutuhan masyarakat akan telur. Keberhasilan usaha pemeliharaan ayam petelur dipengaruhi 3 faktor; kualitas bibit, kualitas dan kuantitas ransum, serta manajemen pemeliharaan. Apabila salah satu faktor tersebut mengalami penyimpangan maka akan terjadi permasalahan atau kegagalan. Konsekuensinya, peternak dituntut dapat mengkombinasikan faktor-faktor tersebut untuk tercipta lingkungan kondusif yang mendukung keberhasilan usaha.

Hasil utama yang diharapkan dari peternakan ayam petelur coklat adalah produksi telur yang bagus, baik kualitas maupun kuantitasnya. Sehingga sudah menjadi tanggung jawab bagi para peternak untuk dapat mencapai produksi telur sesuai kemampuan ayam dan mempertahankan telur pada keadaan standar.

Realitanya, di lapangan menunjukkan bahwa produktivitas ayam petelur yang dihasilkan oleh masing-masing peternak tidak selamanya berada pada titik optimal. Kemungkinan, masalah ini disebabkan ketidaktahuan dan kurang perhatian peternak terhadap pemeliharaan ayam petelur. Faktor yang mempengaruhi produksi telur diantaranya: perkandangan, bibit, ransum, dan kondisi kesehatan ayam.

Pada faktor pemberian ransum, ternak unggas dapat tumbuh cepat dan besar, bertelur sesuai kemampuannya, serta tumbuh sehat membutuhkan ransum yang mengandung 6 macam gizi. Keenam gizi tersebut meliputi: protein dengan kandungan asam amino yang cukup, karbohidrat, lemak, mineral, vitamin, dan air.

Ayam ras petelur sangat sensitif terhadap perubahan dan kualitas ransum yang diberikan. Ransum jenis layer yang diberikan akan berpengaruh terhadap tingkat 
produktivitas telur, baik kualitas maupun kuantitasnya. Proporsi ransum yang diterapkan oleh peternak berbeda-beda, khususnya porsi pemberian ransum pagi dan siang hari. Hasil penelitian Oktasari (2016) menunjukkan bahwa pemberian ransum ayam petelur coklat periode layer strain Isa Brown dengan persentase pemberian antara lain 30:70\%; 40:60\%; 60:40\%; dan 70:30\% berpengaruh nyata terhadap produksi awal 5\%.

Begitu juga mengenai pola pemberian ransum yang diterapkan peternak. Umumnya, ransum ayam ras petelur periode layer yang diberikan berdasarkan faktor kebiasaan semata, baik terkait waktu atau frekuensi. Sementara, secara teknis terdapat waktu pemberian dan frekuensi tertentu sesuai rekomendasi dari pembibit ayam ras komersial. Dengan demikian, diperlukan kajian mengenai metode atau frekuensi pemberian ransum, supaya terdapat keselarasan antara kemampuan ayam dalam memproduksi telur dan manajemen pemeliharaan yang sedang dijalankan.

\section{MATERI DAN METODE PENELITIAN}

Pengumpulan data penelitian dilaksanakan mulai tanggal 10 April sampai dengan 10 Juli 2017 di Abas Farm Desa Ponggok, Kecamatan Ponggok, Kabupaten Blitar.

Materi penelitian adalah ayam petelur coklat ISA Brown berumur 30 minggu dengan bobot rata-rata $1925 \pm 133$, sebanyak 400 ekor. Ransum yang digunakan berupa ransum jadi LP-3 MASTER dari pabrik pakan PT. CJ FEED JOMBANG.

Tabel 1. Komposisi Nutrisi Ransum Pakan Jadi

\begin{tabular}{ccc}
\hline \hline & Kandungan Nutrisi Pakan Jadi \\
\hline Kadar air & Max & $13 \%$ \\
Protein & Min & $17-19 \%$ \\
Lemak & Max & $3-5 \%$ \\
Serat kasar & & $6 \%$ \\
Abu & & $14 \%$ \\
Kalsium & & $3.3-3.9 \%$ \\
Pospor & & $0.7-0.9 \%$ \\
\hline
\end{tabular}

Keterangan: Hasil Label Nutrisi Pakan PT. CJ FEED JOMBANG

Pemeliharaan ditempatkan pada tipe kandang opened house yang membujur dari arah timur ke barat dengan ukuran ( 27 x 5 x 3,5 meter ). Atap kandang tipe monitor berbahan asbes dan ditopang dengan batang tarik berbahan kayu. Ayam ditempatkan pada sistem cage atau kandang battery bambu berukuran P x L x T $(45 \times 45 \times 20 \mathrm{~cm})$. Konstruksi battery disusun 2 tingkat saling berhadapan (flat deck) dengan sudut kemiringan $15^{\circ}$.Tempat ransum 
terbuat dari paralon (PVC) berbentuk memanjang dengan diameter $10 \mathrm{~cm}$ dan kedalaman 7 $\mathrm{cm}$. Tempat minum berupa nipple dringker (1 nipple untuk 2 ekor ayam). Penambahan cahaya malam menggunakan lampu neon berwarna putih.

Metode penelitian adalah percobaan dengan Rancang Acak Lengkap (RAL) yang terdiri dari 4 perlakuan dan 5 kali ulangan. Frekuensi pemberian ransum terdiri dari; $\mathrm{P}_{0}$ : pemberian ransum 2 kali, $\mathrm{P}_{1}$ : pemberian ransum 3 kali, $\mathrm{P}_{2}$ dan $\mathrm{P}_{3}$ sebanyak 4 kali dengan waktu yang berbeda. Variabel yang diukur adalah konsumsi pakan, produksi telur (hen day production), berat telur, dan feed convertion ratio. Data dianalisis dengan sidik ragam, dan dilanjutkan dengan uji Duncant.

\section{HASIL DAN PEMBAHASAN}

\section{Pengaruh Perlakuan Terhadap Konsumsi Ransum (Feed Intake)}

Konsumsi ransum yang diberikan ayam ras menjadi salah satu hal terpenting yang dapat mempengaruhi bobot telur. Kualitas ransum yang kurang baik akan menghasilkan kualitas telur menjadi rendah. Nutrien dalam ransum yang dapat mempengaruhi kualitas telur antara lain; protein, mineral, dan vitamin (Saputra dkk., 2016). Secara statistik rata-rata konsumsi ransum ayam ras selama penelitian disajikan pada Tabel 4.

Tabel 2. Rerata Konsumsi Ransum (Gram/Hari/ Ekor) Selama Penelitian

\begin{tabular}{ccc}
\hline No & Perlakuan & Rata-rata \\
\hline 1 & P 0 & $124.39^{\mathrm{a}}$ \\
2 & P 1 & $127.86^{\mathrm{a}}$ \\
3 & P 2 & $124.77^{\mathrm{a}}$ \\
4 & P 3 & $124.20^{\mathrm{a}}$ \\
\hline
\end{tabular}

\section{Keterangan:}

Superskrip yang sama pada baris yang sama menunjukkan tidak berbeda nyata $(p>0.05)$

Tabel 4. di atas menunjukkan bahwa rerata konsumsi ransum antar perlakuan dari tertinggi sampai terendah berturut-turut $\mathrm{P} 1 ; 127.86$ gram/hari/ekor, $\mathrm{P} 2 ; 124.77$ gram/hari/ekor, P0; 124.39 gram/hari/ekor, dan P3; 124.20 gram/hari/ekor.

Data dan analisis sidik ragam (ANOVA) rerata tingkat konsumsi ransum menunjukkan bahwa secara statistik perlakuan frekuensi pemberian ransum yang berbeda tidak berpengaruh nyata terhadap tingkat konsumsi ransum ayam ras petelur coklat. Hal ini 
disebabkan beberapa faktor yang terjadi selama penelitian. Faktor tersebut diantaranya: tingkat palatabilitas tinggi.

Tingginya palatabilitas ransum berkaitan dengan upaya pemenuhan terhadap kebutuhan nutrisi, dengan demikian palatabilitas tinggi memiliki kecenderungan adanya kekurangan kualitas ransum. Hal ini tampak dengan sedikitnya sisa ransum per hari.

Palatabilitas juga berkaitan dengan warna, aroma, dan bentuk. Ransum yang disediakan dalam bentuk crumble (butiran) lebih disukai daripada bentuk mash (tepung). Sehingga jatah ransum yang diberikan antar perlakuan cenderung selalu termakan habis.

Suhu lingkungan relatif rendah (dingin) pada pagi dan malam hari menyebabkan ayam pada masing-masing perlakuan cenderung mengkonsumsi ransum lebih banyak untuk memenuhi kebutuhan energi. Rasyaf (2007) menyatakan bahwa konsumsi ransum ayam petelur erat kaitannya dengan status kesehatan ayam, produksi dan temperatur lingkungan.

Selain itu, konsumsi ransum juga dipengaruhi oleh faktor pencahayaan. Penambahan cahaya malam dapat merangsang ayam untuk menghabiskan sisa-sisa ransum diwaktu siang. Hal ini selaras dengan pernyataan Sulistyoningsih (2009) bahwa cahaya merupakan stimulant positif bagi hipotalamus. Pancaran cahaya membawa gelombang elektromagnetik yang menggertak ayam untuk merangsang aktivitas hipotalamus.

Cahaya secara tidak langsung dapat meningkatkan konsumsi ransum, dalam hal ini konsumsi protein, dan dapat disamakan sebagai metode pemberian ransum. Unggas lebih responsif pada perlakuan cahaya dibanding perlakuan panas.

Tingkat kebutuhan konsumsi harian ayam petelur pada penelitian ini berbeda dengan hasil yang dicapai Bungatang (2016). Rerata konsumsi harian yang dihasilkan pada penelitian ini lebih tinggi (124,2-127,8 g) dibandingkan dengan hasil penelitian Bungatang (2016) yang berkisar pada tingkat 113-117 g. Terjadinya perbedaan ini disebabkan oleh adanya perbedaan bobot, umur, dan perbedaan temperatur lingkungan.

Tinggi rendahnya tingkat konsumsi ransum juga disebabkan adanya perbedaaan kondisi lingkungan, status kesehatan ayam dan ransum. Sehingga performa produksi cenderung di bawah standar pembibit ayam. Selain tingkat palatabilitas ransum, faktor selera individu yang berbeda-beda mempengaruhi jumlah ransum yang dikonsumsi. Untuk memenuhi kebutuhan pokok dan memproduksi telur yang optimal, dalam ransum harus tersedia; protein, energi, vitamin mineral, dan air yang cukup

Sejalan dengan pernyataan Sultoni dkk., (2006) bahwa tinggi rendahnya kandungan energi ransum dapat mempengaruhi banyak sedikitnya konsumsi ransum, disamping itu konsumsi ransum juga dipengaruhi oleh beberapa faktor yaitu; macam ransum, ransum yang berupa hasil sampingan akan berlainan dengan ransum yang bukan yang bukan hasil sampingan; palatabilitas, ransum yang tercemar jamur akan berlainan dengan ransum yang tidak tercemar; faktor toksik, ransum yang toksik akan dapat menghambat proses metabolisme.

\section{Pengaruh Perlakuan Terhadap Produksi Telur (Hen Day Production)}

Persentase produksi telur harian (Hen Day Production) dihitung dari jumlah produksi telur yang diperoleh dibagi jumlah ayam yang dipelihara dikalikan 100\%. Perbedaan tinggi 
rendahnya produktifitas telur ayam ras dipengaruhi beberapa faktor, antara lain; genetik, kualitas dan kuantitas ransum yang diberikan, suhu lingkungan, kesehatan ternak dan aktifitas atau penanganan ternak yang dipelihara. Rataan produksi telur (HDP) masing-masing perlakuan selama penelitian disajikan pada Tabel 5.

Tabel 3. Rerata HDP (\% ) Selama Penelitian

\begin{tabular}{ccc}
\hline No & Perlakuan & Rata-rata HDP (\%) \\
\hline 1 & P 0 & $84.79^{\mathrm{a}}$ \\
2 & P 1 & $90.30 \mathrm{~b}$ \\
3 & P 2 & $81.73 \mathrm{a}$ \\
4 & P 3 & $86.45 \mathrm{a}$ \\
\hline
\end{tabular}

\section{Keterangan:}

Superskrip yang berbeda menunjukkan perbedaan yang nyata $(\mathrm{p}<0.05)$

Berdasarkan hasil analisa sidik ragam (ANOVA) diketahui bahwa berbagai frekuensi pemberian ransum yang berbeda berpengaruh nyata $(\mathrm{p}<0,05)$ terhadap HDP $(\%)$. Data penelitian menunjukkan bahwa rataan HDP tertinggi terletak pada perlakuan P1 dan rataan terendah berada pada perlakuan P2. Jika dilihat dari rataan HDP maka frekuensi pemberian ransum 3 kali sehari memberikan kontribusi yang terbaik terhadap performa produksi ternak pada waktu penelitian.

Nilai rataan HDP perlakuan P1 mencapai 90.30\% sedang perlakuan P2 menempati posisi terendah dengan nilai HDP $81.73 \%$. Standart acuan untuk HDP dari ISA Brown pada umur 30-38 minggu adalah 93.5\%. Perolehan nilai HDP pada masing-masing perlakuan yang berada di bawah standart ISA Brown tersebut dapat disebabkan karena perbedaan kondisi lingkungan, status kesehatan ayam, status manajemen farm.

Hasil pengamatan menunjukkan bahwa secara umum pemberian ransum 3 kali sehari (P1) memiliki beberapa kelebihan dibanding perlakuan lain. Kelebihan tersebut diantaranya; kualitas ransum P1 lebih baik, karena ransum diberikan secara cukup dan dalam kondisi segar. Pola pemberian ransum P1 juga dapat memperlambat kehilangan atau penguapan nutrisi ransum akibat paparan cahaya dan suhu kandang saat panas.

Kelebihan lain pemberian ransum P1 adalah dapat memperlambat adanya kemungkinan kontaminasi bibit penyakit yang dibawa lalat atau serangga lain ketika ransum belum sepenuhnya dikonsumsi dan memperlambat tumbuhnya jamur pada ransum. 
Secara operasional, pemberian ransum P1 dapat memberikan stimulus pada ayam untuk terus makan. Resiko cekaman akibat aktifitas anak kandang relatif kecil sehinggga tidak menimbulkan stres yang berakibat turunnya produksi telur. Pemberian ransum P1 dapat mengurangi cekaman panas yang berlebih akibat dari proses metabolisme dan suhu lingkungan yang tinggi.

Tamzil (2014) menyatakan bahwa ternak unggas yang menderita stres panas menyebabkan labilnya senyawa-senyawa tertentu, seperti enzim, sehingga enzim tidak dapat berfungsi sebagaimana mestinya dan selanjutnya mempengaruhi kondisi fisiologis dan hormonal di dalam tubuh ternak unggas. Stres panas pada unggas memicu munculnya berbagai penyakit serta mempengaruhi pertumbuhan dan produksi telur.

Jika dilihat dari nila rataan HDP yang baik maka perlakuan P1 dengan ransum jadi pabrikan memberikan pengaruh yang terbaik terhadap pemenuhan nutrisi pada ransum terutama kandungan protein. Kandungan nutrisi yang terdapat pada ransum pabrikan mempunyai gizi seimbang untuk ayam ras petelur periode layer, baik imbangan kalsium dan pospor, protein, lemak dan serat kasar.

Sedangkan nilai persentase HDP terendah berada pada perlakuan P2. Rendahnya tingkat produktifitas tersebut bisa jadi disebabkan pola pemberian ransum yang belum sesuai diterapkan pada sistem pemberian ransum secara manual. Frekuensi pemberian ransum yang terlalu sering menyebabkan cekaman pada ternak. Sehingga keadaan tersebut mempengaruhi produktifitas dan penyerapan nutrisi dalam tubuh. Hal ini dibuktikan dengan mundurnya waktu peneluran sehingga telur masih terlihat menjelang petang hari.

Sultoni dkk., (2006) menyatakan bahwa protein ransum yang dikonsumsi akan dipecah menjadi asam amino dan diserap oleh tubuh untuk disusun menjadi protein jaringan dan telur. Meskipun protein ransum sesuai kebutuhan, tetapi defisiensi asam amino esensial dapat berdampak pada efisiensi penggunaan protein untuk pembentukan jaringan tubuh atau produksi telur menurun. Hasil laju produksi yang diperoleh dari penelitan mengenai pengaruh frekuensi pemberian ransum yang berbeda dapat dilihat pada gambar berikut:

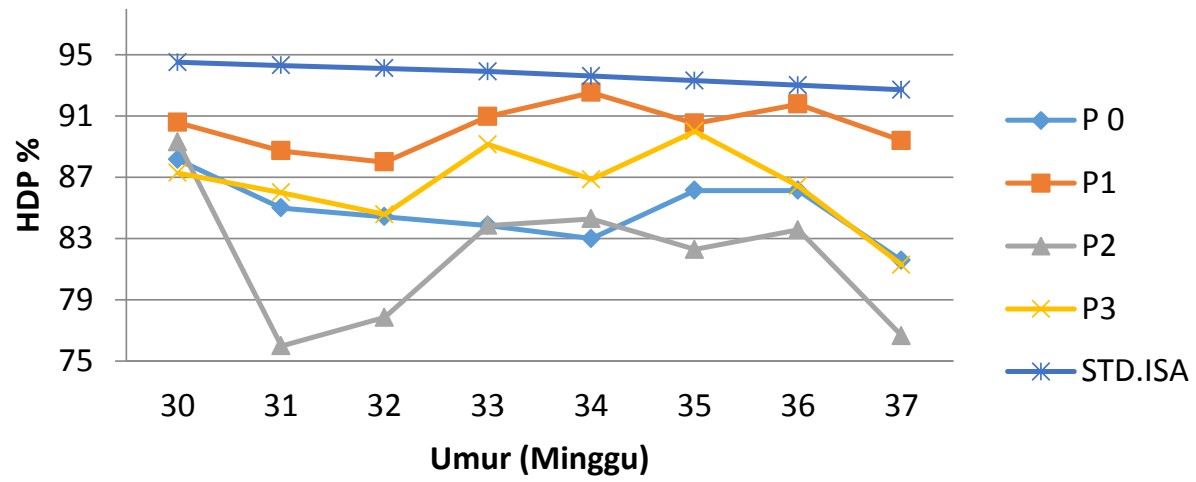

Gambar 1. Laju Hen Day Production Selama Penelitian.

Perlakuan P1 mampu menghasilkan jumlah telur lebih banyak dan laju produksi yang tidak terlalu fluktuatif atau memiliki stabilitas produksi lebih baik dibandingkan perlakuan P2 
dan P3. Nilai HDP menjadi penting karena adanya perubahan selera masyarakat yang cenderung memilih satuan berat telur yang sama dengan jumlah telur lebih banyak dibandingkan yang isinya lebih sedikit.

Laju HDP menunjukkan bahwa hasil penelitian masih dibawah standar pembibit. Laju HDP pada masing-masing perlakuan yang berada di bawah standart ISA Brown tersebut dapat disebabkan karena perbedaan kondisi lingkungan, status kesehatan ayam, dan status manajemen farm.

Rerata hasil HDP ayam ISA Brown pada penelitian Bungatang (2016) berkisar 58,55$62,85 \%$. Sementara nilai HDP pada hasil penelitian ini lebih tinggi dibandingkan dengan hasil penelitian Bungatang (2016). Terjadinya perbedaan ini disebabkan oleh adanya perbedaan kandungan nutrisi dalam ransum yang diberikan terutama imbangan protein dan energi. Selain nutrisi faktor umur dan temperatur lingkungan juga dapat mempengaruhi performa produksi ternak

Selanjutnya pada hasil penelitian lain, rerata produksi ayam petelur umur 32-44 minggu berkisar 79,04-80,42\%. Sedangkan hasil HDP pada penelitian ini lebih tinggi dari hasil penelitian tersebut. Penelitian Fenita dkk., (2010) menyatakan bahwa perbedaan kandungan nutrisi dengan selisih kecil tidak mempengaruhi produktifitas ternak selama tingkat konsumsi ransum ayam petelur tidak berbeda.

Selaras dengan penelitian Albana (2014) yang menyatakan bahwa produksi telur yang tinggi pada kandang individu berbanding terbalik dengan konversi ransum. Rataan hen day yang tinggi memiliki nilai konversi ransum rendah. Penelitian menunjukkan ayam ras yang dipelihara pada kandang individu memiliki nilai konversi ransum yang lebih kecil dibandingkan pada koloni. Konversi ransum yang rendah menunjukkan ayam lebih efisien dalam mengubah ransum menjadi telur.

\section{Pengaruh Perlakuan Terhadap Berat Telur (Egg Weight)}

Secara statistik rata-rata bobot telur ayam ras selama penelitian disajikan pada Tabel 4.

Tabel 4. Rerata Bobot Telur

\begin{tabular}{ccc}
\hline No & Perlakuan & Rata-rata \\
\hline 1 & P $~$ & $53.30^{\mathrm{a}}$ \\
2 & P 1 & $56.31^{\mathrm{a}}$ \\
3 & P 2 & $51.60^{\mathrm{a}}$ \\
4 & P 3 & $49.60^{\mathrm{a}}$ \\
\hline
\end{tabular}

\section{Keterangan:}


Superskrip yang sama pada baris yang sama menunjukkan tidak berbeda nyata $(\mathrm{p}>0.05)$

Hasil analisa sidik ragam menunjukkan bahwa perlakuan frekuensi pemberian ransum berpengaruh tidak nyata $(\mathrm{P}>0.05)$. Bobot telur yang tidak berbeda nyata ini disebabkan oleh tingkat konsumsi antarperlakuan yang tidak berbeda dan tingkat keseragaman bobot ayam relatif sama. Di sisi lain rendahnya bobot telur dapat dipengaruhi oleh beberapa faktor. Faktor tersebut seperti: status kesehatan ternak, penyerapan nutrsi ransum, cekaman, dan suhu lingkungan.

Konsumsi ransum yang tidak berbeda menyebabkan nutrisi yang diterima oleh ayam seperti; protein, serat kasar, lemak, mineral, vitamin dan nutrisi lainnya relatif sama sehingga bobot telur yang dihasilkan antar perlakuan tidak jauh berbeda. Saputra dkk., (2016) menyatakan bahwa konsumsi ransum menjadi salah satu faktor terpenting yang mempengaruhi bobot telur. Faktor makanan terpenting yang diketahui mempengaruhi besar telur adalah protein dan asam amino yang cukup dalam ransum.

Perolehan rata-rata bobot telur dari setiap perlakuan baik P0;53.60, P1;56.31, P2;51.60 dan P3;49.60 masih berada di bawah bobot telur standar acuan ISA Brown. Faktor ransum terpenting yang diketahui mempengaruhi bobot telur adalah protein dan asam amino. Adanya level protein yang berbeda pada ransum pabrik memungkinkan ayam tidak selalu mendapat porsi nutrisi yang cukup. Laju bobot telur dari masing-masing perlakuan selama penelitian dapat dilihat pada gambar 2 .

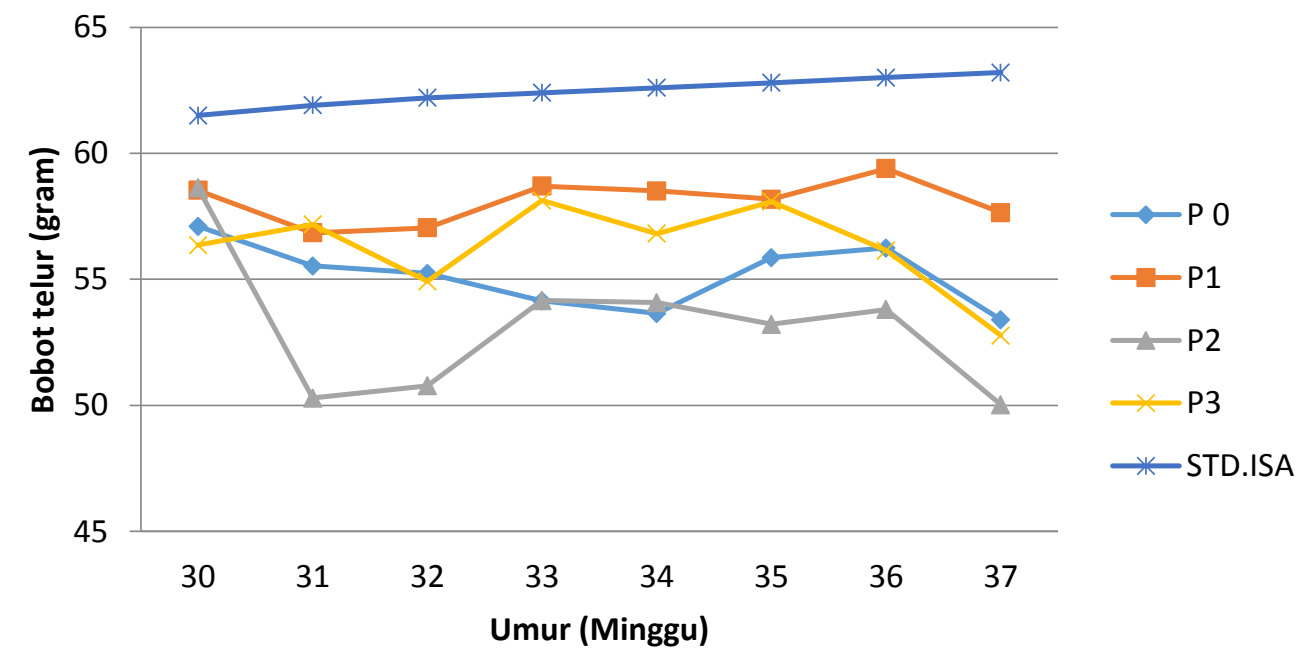

Gambar 2. Laju Bobot Telur Selama Penelitian

Hasil laju bobot telur menunjukkan bahwa bobot telur yang dihasilkan antarperlakuan masih rendah di bawah standar acuan bobot telur ISA Brown. Serupa dengan faktor yang mempengaruhi tingkat konsumsi ransum, ayam ISA Brown yang dipelihara pada tempat 
penelitian tidak mampu menunjukkan keunggulan genetisnya. Hal ini dikarenakan ayam strain ISA Brown yang dipelihara pada iklim tropis dipengaruhi oleh suhu atau temperatur lingkungan yang berbeda dengan negara asalnya.

Hasil bobot telur pada penelitian ini tidak jauh berbeda dengan hasil penelitian yang dicapai Palupi dkk., (2014). Rerata berat telur ayam strain ISA Brown umur 30 minggu pada penelitian tersebut berkisar 53,55-55,80 g. Keadaan ini berkaitan dengan perbedaan kandungan nutrisi yang selisihnya kecil dan tingkat konsumsi ransum yang tidak berbeda menyebabkan nutrisi yang dicerna oleh ayam relatif sama. Keadaan ini menyebabkan berat telur yang dihasilkan relatif sama.

Bobot telur dipengaruhi oleh beberapa faktor seperti; sifat genetik, tingkat dewasa kelamin, ransum, obat-obatan, umur dan bobot ayam. Nilai koefisien keragaman bobot ayam terhitung 7\% dari 400 ekor ternak yang ditimbang sebelum penelitian. Sejalan dengan pernyataan Hartono dan Kurtini (2015) bahwa bobot ayam dan bobot telur mempunyai korelasi positif, ayam dengan bobot yang lebih berat memproduksi telur yang lebih berat dibandingkan ayam dengan bobot tubuh yang ringan.

Kualitas telur umumnya bergantung pada saat sebelum dan atau sesudah oviposisi telur itu sendiri. Telur ketika berada dalam saluran reproduksi induk ayam selama lebih dari 24 jam lamanya dan mengalami banyak proses yang mempengaruhi kualitasnya. Yuwanta, (2004) menyatakan bahwa faktor-faktor yang mempengaruhi kualitas telur sebelum oviposisi antara lain faktor genetik, umur dan berat induk, nutrisi ransum, penyakit, dan suhu lingkungan.

Protein adalah polimer dari asam amino yang terdiri dari atas satu atau dua rantai polipeptida. Asam amino di dalam protein dibutuhkan ternak unggas untuk pembentukan sel, mengganti sel mati, membentuk jaringan tubuh seperti daging, kulit, telur, embrio, dan bulu. Unggas yang tidak diberi makan protein akan tetap kecil dan tumbuh lambat atau tidak bertambah besar (Ketaren, 2010).

Ayam ras petelur sangat sensitif terhadap perubahan kualitas ransum. Perbaikan mutu genetik yang terus menerus dilakukan pembibitan membawa konsekuensi pada kebutuhan ransum yang semakin spesifik. Kualitas ransum jenis layer yang diberikan akan berpengaruh terhadap tingkat produktifitas telur baik presentase produksinya maupun ukuran dan bobot telur yang dihasilkan (Fadilah dan Fathkuroji, 2013).

\section{Pengaruh Perlakuan Terhadap Feed Convertion Ratio (FCR)}

Konversi ransum menunjukkan kemampuan ternak dalam mengubah ransum menjadi produk telur. Nilai konversi ransum merupakan perbandingan antara jumlah ransum yang dikonsumsi dengan jumlah bobot telur yang dihasilkan. Rerata nilai FCR antar perlakuan disajikan dalam tabel berikut:

Tabel 5. Nilai FCR Selama Penelitian

No Perlakuan $\quad$ Rata-rata




\begin{tabular}{lll}
\hline 1 & P & $2.25^{\mathrm{a}}$ \\
2 & P 1 & $2.18^{\mathrm{a}}$ \\
3 & P 2 & $2.33^{\mathrm{a}}$ \\
4 & P 3 & $2.24^{\mathrm{a}}$ \\
\hline
\end{tabular}

\section{Keterangan:}

Superskrip yang sama pada baris yang sama menunjukkan tidak berbeda nyata $(\mathrm{p}<0.05)$

Tabel 5. di atas menunjukkan bahwa rerata FCR antar perlakuan dari terendah sampai tertinggi berturut-turut $\mathrm{P} 1 ; 2.18, \mathrm{P} 3 ; 2.24$, P0; 2.25, dan nilai FCR tertinggi yaitu P2; 2.33 . Data dan analisis sidik ragam rerata FCR selengkapnya terdapat pada Lampiran 3.

Berdasarkan hasil analisa sidik ragam perlakuan tidak berpengaruh nyata terhadap FCR $(\mathrm{P}>0.05)$. Hal ini dikarenakan ransum yang diberikan antarperlakuan adalah ransum dengan kandungan energi metabolisme (EM), protein kasar (PK), serat kasar (SK), mineral, dan feed suplement yang sama dan seimbang. Sehingga pada tingkat konsumsi dan bobot telur yang relatif sama antarperlakuan menyebabkan nilai FCR tidak jauh berbeda.

Rataan konversi ransum yang disajikan di atas menunjukkan bahwa perlakuan P1 menghasilkan nilai rataan FCR terendah, yaitu 2.1. Hal ini berarti pada perlakuan P1 rata-rata seekor ternak membutuhkan ransum sebanyak $2.1 \mathrm{~kg}$ untuk menghasilkan $1 \mathrm{~kg}$ telur. Nilai FCR tersebut menggambarkan efisiensi yang baik pada ternak dalam mengubah ransum menjadi produk telur.

Nilai FCR tertinggi berada pada perlakuan P2 yang mencapai 2.33 sedang perlakuan P1 menempati posisi terendah dengan nilai FCR 2.21. Standart acuan untuk nilai FCR dari ISA Brown pada umur 30-38 minggu adalah 1.93 Perolehan nilai FCR pada masing-masing perlakuan yang mendekati standar FCR ISA Brown adalah perlakuan P1. Dengan pola P1atau pola frekuensi pemberian ransum 3 kali dapat mengoptimalkan produktifitas.

Hasil pengamatan grafik laju FCR selama penelitian dapat diamati pada gambar 3. 


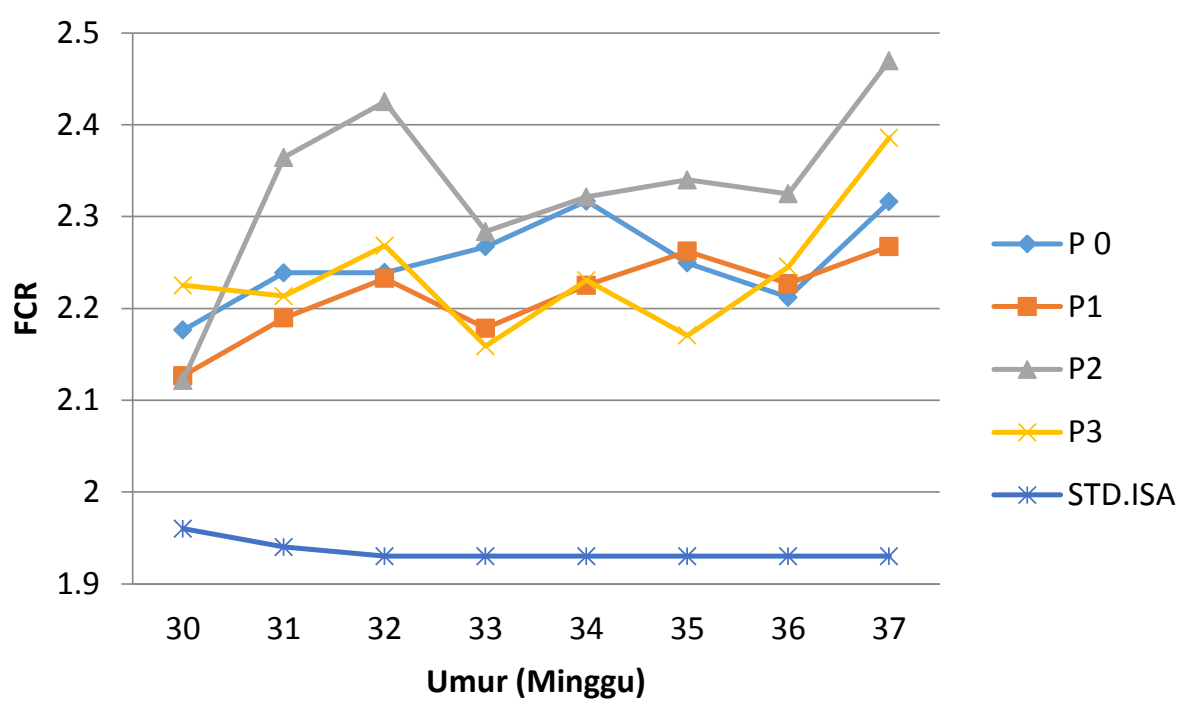

Gambar 3. Laju FCR Selama Penelitian

Laju FCR di atas menunjukkan bahwa nilai FCR antarperlakuan masih lebih tinggi dari standar acuan FCR ayam ISA Brown. Laju FCR pada grafik menunjukkan antarperlakuan relatif sama. Hal ini terjadi karena pada tingkat konsumsi ransum dan bobot telur yang relatif sama menyebabkan nilai FCR tidak berbeda jauh.

Faktor lain yang mempengaruhi performa ayam ISA Brown dapat disebabkan karena perbedaan kondisi lingkungan, status kesehatan ayam, status manajemen farm. Sehingga sifat keunggulan ayam strain ISA Brown tidak bisa dimunculkan pada lokasi penelitian.

Konversi ransum yang tinggi disebabkan adanya tingkat konsumsi ransum yang tinggi sedangkan jumlah bobot telur yang dihasilkan rendah. Sedangkan nilai koefisien ransum yang rendah disebabkan perlakuan tersebut menghasilkan jumlah bobot telur yang optimal dengan tingkat konsumsi ransum yang cukup tinggi.

Senada dengan Lokapirnasari (2011) yang menyatakan bahwa kandungan nutrisi ransum terutama sumber energi dan protein yang dikonsumsi dapat mempengaruhi nilai konversi ransum. Jumlah nutrisi yang berbeda pada ransum akan mempengaruhi produktifitas telur yang dihasilkan. Kadar energi ransum sangat menentukan jumlah ransum yang dikonsumsi. Kadar energi yang tinggi menyebabkan konsumsi ransum sedikit.

Berdasarkan penelitian Fenita dkk., (2010) rerata nilai konversi ransum pada ayam umur 32-44 minggu berkisar 2,46-2,55. Sementara nilai konversi ransum ayam petelur yang dihasilkan pada penelitian ini lebih rendah dibandingkan dengan hasil penelitian Fenita dkk., (2010). Perbedaan ini disebabkan oleh adanya perbedaan tingkat konsumsi ransum bobot telur yang dihasilkan ternak serta adanya perbedaan temperatur lingkungan.

Parameter terbaik untuk menilai mutu ransum adalah dengan melihat efisiensi penggunaan ransum tersebut. Konversi ransum sangat penting diperhatikan karena erat kaitannya dengan biaya produksi. Tinggi rendahnya nilai konversi bergantung keseimbangan nutrisi dalam ransum. Semakin rendah nilai konversi makan semakin efisien. 
Selaras dengan pernyataan Sultoni dkk., (2006) bahwa fungsi dari perhitungan konversi ransum adalah untuk mengevaluasi kualitas dan kuantitas ransum yang diberikan dan selanjutnya dikonversikan dalam $1 \mathrm{~kg}$ telur. Semakin kecil nilai konversi ransum maka akan semakin efisien.

\section{KESIMPULAN}

Berdasarkan hasil penelitian yang dilakukan, maka dapat diambil kesimpulan sebagai berikut:

1. Frekuensi pemberian ransum yang berbeda berpengaruh nyata $(\mathrm{p}<0.05)$ terhadap persentase produksi telur harian (hen day production)

2. Frekuensi pemberian ransum yang berbeda pada ayam ras petelur coklat tidak berpengaruh nyata ( $\mathrm{p}>0.05)$ terhadap bobot telur, konsumsi ransum (feed intake) dan Feed Convertion Ratio (FCR).

\section{DAFTAR PUSTAKA}

Albana H. I. 2014. Produktivitas Ayam Ras dan Arab Menghasilkan Telur Omega-3 yang dipelihara pada kandang Koloni dan Individu. Skripsi. Departemen Ilmu Produksi dan Teknologi Peternakan. Institut Pertanian Bogor.

Bungatang. 2016. Pengaruh Tepung Limbah Biji Kakao (Theobroma Cocao L) Yang difermentasi Bakteri Selulotik terhadap Produktivitas Ayam Petelur. Skripsi. Fakultas Peternakan. Universitas Hasanuddin Makasar.

Fadilah, R. dan Fathkuroji. 2013. Memaksimalkan Produksi Ras Petelur.

PT. Agromedia Pustaka. Jakarta.

Fenita. Y.,U. Santosa dan H. Prakoso. 2010. Pengaruh Suplementasi asam Amino Lisin, Metionin, Triptopan dalam Ransum Berbasis Lumpur Sawit Fermentasi terhadap Performa Produksi dan Kualitas Telur Ayam Ras. Jurnal Saint Peternakan Indonesia Vol. 5. No.2. (105-114).

Handayani. I. 2014. Efisiensi Ekonomi Frekuensi Pemberian Pakan pada Pemeliharaan Ayam Broiler. Skripsi. Universitas Hasanudin Makasar.

Hartono. M. Dan T., Kurtini. 2015. Pengaruh Probiotik terhadap Performa Ayam Petelur. Jurnal Penelitian Pertanian Terapan. Vol 15 (3) : 214-219. 
ISA Company. 2009. Nutrition Management Guide.A Hendrix Genetik Company. Www.Hendrix-Genetics.Com. Diakses 5 Maret 2017.

Kartasudjana, R. dan E. Suprijatna. 2006. Manajemen Ternak Unggas. Penebar Swadaya. Jakarta.

Ketaren, P. P. 2010. Kebutuhan Gizi Ternak Unggas di Indonesia. Wartazoa Vol. 20. No.4 (172-180).

Lengkong E.M., J. R. Leke., L. Tangkau., dan S. Sane. 2015. Substitusi Sebagian Ransum dengan Tepung Tomat Merah (Solanum Lycopersicum L.) Terhadap Penampilan Produksi Ayam Ras Petelur. Jurnal Zootek. Vol.35 No.2 (24-257).

Lokapirnasari, W. P., Soewarno, Dan Y. Dhammayanti. 2011. Potensi Crude Spirulina Terhadap Protein Effisiensi Rasio Pada Ayam Petelur. Jurnal Ilmiah Kedokteran Hewan Vol. 2,No. 1, April 2011.

Nurcholis, D. Hastuti dan B. Sutisno. 2009. Tatalaksana Pemeliharaan Ayam Ras Petelur Periode Layer di Populer Farm Desa Kuncen Kecamatan Mijien Kota Semarang. Mediagro Vol 5. No 2 (38-49).

Oktasari, A. 2016. Perbedaan Pemberian Porsi Pakan terhadap Produksi Awal Ayam Petelur. Skripsi. Universitas Islam Balitar.

Palupi, R., L. Abdullah, D.A. Astuti, dan Sumiarti. 2014. Pemanfaatan Tepung Pucuk Indigofera sp. sebagai Bahan Pakan Substitusi Bungkil Kedelai dalam Ransum Ayam Petelur. JITV 19 (3): 210-219.

Primaditya F.M., S. Hidanah, dan Soeharsono. 2015. Analisi Pendapatan dan Produktivitas Ayam Petelur Sistem Closed House dengan Penggunaan Mesin Pakan Otomatis dan Manual di Kuwik farm, Kecamatan Badas, Pare. Jurnal Agroveteriner Vol. 3 No. 2 (99-106)

Rasyaf, M 2007. Penyajian Makanan Ayam Petelur. Kanisius . Yogyakarta.

Risnajati, D. 2011. Pengaruh Pengaturan Waktu Pemberian Air Minum Yang Berbeda Temperature Terhadap Performa Ayam Petelur Periode Grower. Sains Peternakan Vol. 9 No 2 (77-81) 
Rusdiansyah, M. 2014. Pemberian Level Energi dan Protein Berbeda terhadap Konsumsi Ransum dan Air serta Konversi Ransum Ayam Buras Fase Layer. Skripsi. Fakultas Peternakan. Universitas Hasanuddin Makasar.

Salele, C.C.L., B. Roimpandey., M.T. Massie., dan P.O.V. Waleleng. 2014. Analisa Penggunaan Faktor Produksi pada Perusahaan Ayam Ras Petelur. Jurnal Zootek. Vol. 34 (Edisi Khusus) (1-14)

Saputra D.R., T. Kurtini, dan Erwanto. 2016. Pengaruh Penambahan Feed Aditif dalam Ransumdengan Dosis yang Berbeda terhadap Bobot Telur dan Nilai Haugh Unit (HU) Telur Ayam Ras. Jurnal Ilmiah Peternakan Terpadu. Vol.4. No. 3 (230-236)

Siahaan, N.B., E. Suprijatna, dan L.D. Mahfudz. 2013. Pengaruh Penambahan Tepung Jahe Merah (Zingiber officinalevar. Rubbum) dalam Ransum terhadap Laju Bobot Badan dan Produksi Telur Ayam kampung Periode Layer. Animal Agricultural Journal. Vol.2 No.1 (478-488).

Sudarmono, A. S. 2007. Pedoman Pemeliharaan Ayam Petelur. Kanisius. Yogyakarta.

Sulistyoningsih, M. 2009. Pengaruh Pencahayaan (Lighting) terhadap Performans dan Konsumsi Protein pada Ayam. Prosiding Seminar Nasional ISBN 976-602-95207-0-5

Sultoni A., A. Malik Dan W. Widodo. 2006. Pengaruh Penggunaan Berbagai Konsentrat Pabrikan Terhadap Optimalisasi Konsumsi Pakan, Hen Day Production dan Konversi Pakan. Jurnal Protein. Vol.14 No.2 (103-107).

Suprijatna, E., U. Atmomarsono dan R. Kartasudjana. 2008. Ilmu Dasar Ternak Unggas. Penebar Swadaya. Bogor

Tamzil, M.H. 2014. Stres Panas pada Unggas: Metabolisme, Akibat dan upaya Penanggulangannya. Wartazoa Vol.24 (2): 57-66. 
Tristanti I. A., E. Widodo dan H. Natsir. 2014. Pengaruh Penambahan Sari Belimbing Wuluh (Averrhoa Blimbi, L) dalam Pakan terhadap Kualitas Ekstrenal Telur Ayam. Jurnal Nutrisi Ternak Vol.1 No. 1 (34-41).

Tugiyanti E. Dan N. Iriyanti. 2012. Kualitas Eksternal Ayam Petelur yang Mendapat Ransum dengan Penambahan Tepung Ikan Fermentasi Menggunakan Isolat Produser Antihistamin. Jurnal Aplikasi Teknologi Pangan. Vol. 1. No 2 (44-47).

Yuwanta, T. 2004. Dasar Ternak Unggas. Kanisius. Yogyakarta. 